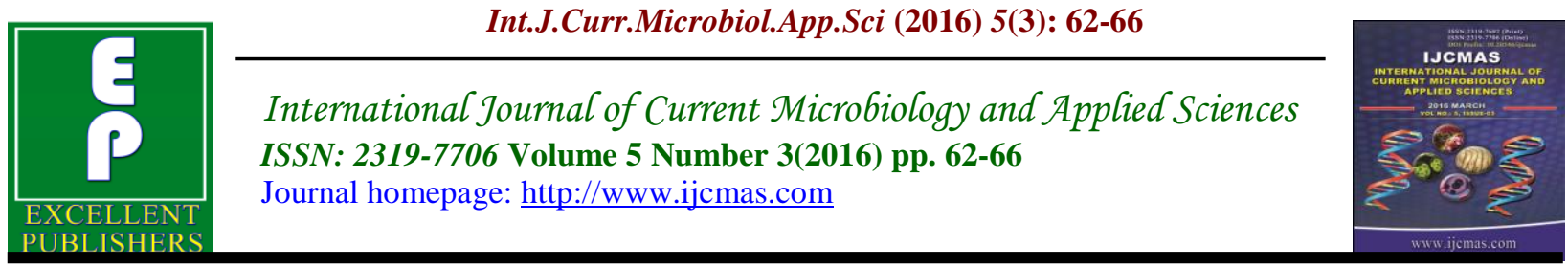

Review Article

http://dx.doi.org/10.20546/ijcmas.2016.503.009

\title{
Arsenal of Endophytic Actinobacterial Microbes
}

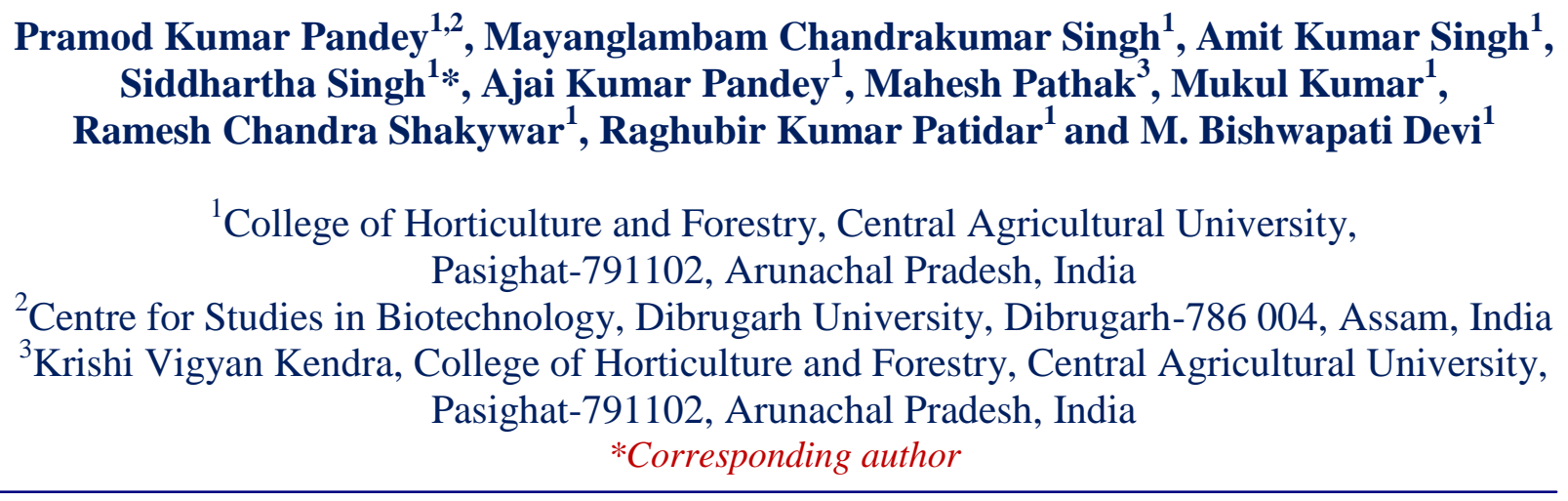

A B S T R A C T

\section{Keywords}

Bioactive compounds, Plant growth, Antifungal, Antibacterial.

\section{Article Info}

Accepted:

07February 2016

Available Online: 10, March 2016
Endophytic actinomycetes are the most exploited group of plant associated microbe utilized in the agricultural based industries. In this review effort will make to summarize the utilization of Endophytic actinomycetes as a booming alternative for agro practices in the place of hazardous chemical. Endophytic actinomycetes were extensively investigated for their antimicrobial properties such as antifugal and antibacterial. They are able to produce a variety of antibiotics and several other bioactive compounds utilized in the agricultural practices which were not previously reported.

\section{Introduction}

Most Plants of the world are a potential reservoir of indigenous microbes chiefly known as endophyte which can reside inside their tissue without giving any visible external symptoms which responsible for nutrient assimilation and their processing, induction of defense system, and synthesis of secondary metabolites (Pandey et al., 2014; Pandey et al., 2016). They may be actinomycetes, bacteria or fungi. They colonizes internal tissues either as obligate or in facultative manner with host plants without causing any immediate negative or external symptom to host and reported to shows the beneficial effects, put forward opportunities for discovering products and processes with potential applications in agriculture, medicine and biotechnology (Pandey et al., 2012; Pandey et al., 2016). Researches are focused on the investigation of actinomycetes endophytic diversity and their relationships with host plants. Several decades of actinomycetes endophytic research resulted in a finding of natural bioactive compounds, and recovering the efficiency of some probable candidates by delightful advantage of genetic engineering which are ever-increasing day by day. 
Production of Antibiotic by Endophyticactinobacteria

Antibiotic production from endophyticactinomycetes associated with plants having medicinal properties hold the ability to inhibit pathogenic fungi, bacteria and virus. A variety of antibiotics have been reported to develop antimicrobial compounds, such as Demethylnovobiocins (Igarashi, 2004), munumbicins A-D (Castillo et al., 2002) and kakadumycins (Castillo et al., 2003). 6Prenylindole having antifungal activity against Fusarium oxysporum isolated from Endophytic actinomycetes Streptomyces sp. TP-A0595 (Igarashi, 2004). Actinomycin D extracted from Endophytic actinomycetes Streptomyces sp. Tc022 associated with root of Alpinia galangal were effective against the fungal pathogen Colletotrichummusae and Candida albicans(Taechowisan et al., 2006). Munumbicins E-4 and Munumbicins E-5from endophytic Streptomyces NRRL 30562 shows broad-spectrum antibacterial properties (Castillo et al., 2006). Saadamycin an antimycotic compound isolated from Endophytic actinomycetes Streptomyces sp. Hedaya48 (El-Gendy and EL-Bondkly, 2010).

\section{Biological Control by Endophytic- actinobacteria}

Biological control and antimicrobial activity of Endophytic actinomycetes is mainly relies on production of cell wall degrading enzyme, production of antibiotics and competition for nutrient utilization by pathogen. They also have ability to eliciting plant induced systemic resistance (ISR). The Endophytic actinomycetes Streptomyces galbus R-5 produces pectinase and cellulase enzyme which helps in cell wall degradation along with actinomycin X2 and fungi chromin compound which elicited jasmonate-associated defence responses in the rhododendron seedlings (Shimizu et al., 2005). Endophytic actinomycetes isolate Streptomyces sp.EN27 and Micromonospora sp. strain EN43 increases resistance in Arabidopsis thaliana against Erwiniacarotovora and F. oxysporum (Conn et al., 2008). They are reported to elicit expression of genes linked with salicylic acid, jasmonic acid and ethylene- dependent signaling pathways (Conn et al., 2008).

\section{Plant Growth Promoting Agents}

Endophytic-actinomycetes benefit to plant growth via the production of plant growth promotion bioactive compounds like cytokinins, auxins, gibberellins or suppress stress harmone ethylene production by synthesis of 1-aminocyclopropane-1carboxylate (ACC) or producing siderophore to improve nutrient uptake (Compant et al., 2005; Sun et al., 2009). Pteridic acids A and B extracted from Endophytic actinomycetes S. hygroscopicus TP-A0451 regulate plant metabolism in their different concentration (Igarashi, 2004). Pathogenic Gram-negative bacteria used $\mathrm{N}$-acyl-L-homoserine lactone (HSL) quorum sensing to control their virulence traits. Hence, to investigate the enzyme that degrade $N$-acyl-L-homoserine lactone (HSL) signal molecule and overcome pathogenecity in such type of microbes is of great importance. The endophyticactinomyecetes isolate Streptomyces LPC029 exhibited HSLacylase activity and able to cleave an amide bond of acyl-side chain in HSL substrate and an in vitro antagonistic test showed partially purified HSL-acylase from the Streptomyces LPC029 inhibit soft rot of potato caused by Pectobacterium carotovorums sp. carotovorum (Chankhamhaengdecha et al., 2013). 
Table.1 Some Bioactive Compounds from the Endophytic actinomycetes

\begin{tabular}{|c|c|c|c|c|c|}
\hline $\begin{array}{c}\text { Bioactive } \\
\text { compounds }\end{array}$ & $\begin{array}{l}\text { Nature of } \\
\text { compound }\end{array}$ & $\begin{array}{l}\text { Nature of } \\
\text { activity }\end{array}$ & $\begin{array}{c}\text { Endophytic } \\
\text { actinomycetes }\end{array}$ & Host plants & References \\
\hline Saadamycin & $\begin{array}{l}\text { Heterocyclic } \\
\text { compound }\end{array}$ & Antifungal & Streptomyces sp. & $\begin{array}{l}\text { Aplysina } \\
\text { fistularis }\end{array}$ & $\begin{array}{l}\text { El-Gendy and } \\
\text { EL-Bondkly, } \\
2010\end{array}$ \\
\hline $\begin{array}{l}\text { Demethylnovobio } \\
\text { cins }\end{array}$ & Coumarins & $\begin{array}{l}\text { Anti- } \\
\text { microbial }\end{array}$ & $\begin{array}{l}\text { Streptomyces sp. } \\
\text { TP-A0556 }\end{array}$ & $\begin{array}{l}\text { Aucuba } \\
\text { japonicaTh } \\
\text { unb }\end{array}$ & Igarashi, 2004 \\
\hline $\begin{array}{l}\text { Munumbicins E-4 } \\
\text { and E-5 }\end{array}$ & Peptides & Antibiotic & $\begin{array}{l}\text { Streptomyces } \mathrm{sp} . \\
\text { NRRL } 30562\end{array}$ & $\begin{array}{l}K . \\
\text { nigriscans }\end{array}$ & $\begin{array}{l}\text { Castillo et al., } \\
2006\end{array}$ \\
\hline $\begin{array}{l}\text { Munumbicins A- } \\
\text { D }\end{array}$ & Peptides & Antibiotic & $\begin{array}{l}\text { Streptomyces sp. } \\
\text { NRRL } 30562\end{array}$ & $\begin{array}{l}\text { Kennedia } \\
\text { nigriscans }\end{array}$ & $\begin{array}{l}\text { Castillo et al., } \\
2002\end{array}$ \\
\hline Kakadumycins & Peptides & Antibiotic & $\begin{array}{l}\text { Streptomyces sp. } \\
\text { NRRL } 30566\end{array}$ & $\begin{array}{l}\text { Grevillea } \\
\text { pteridifolia }\end{array}$ & $\begin{array}{l}\text { Castillo et al., } \\
2003\end{array}$ \\
\hline 6-Prenylindole & Alkaloids & Antifungal & $\begin{array}{l}\text { Streptomyces sp. } \\
\text { TP-A0595 }\end{array}$ & $\begin{array}{l}\text { Allium } \\
\text { tuberosum }\end{array}$ & Igarashi, 2004 \\
\hline $\begin{array}{l}\text { Cedarmycins } \mathrm{A} \\
\text { and } \mathrm{B}\end{array}$ & $\begin{array}{l}\text { Butyrolacton } \\
\text { es }\end{array}$ & Antifungal & $\begin{array}{l}\text { Streptomyces sp. } \\
\text { TP-A0456 }\end{array}$ & $\begin{array}{l}\text { Cryptomeri } \\
a \\
\text { japonica }\end{array}$ & Igarashi, 2004 \\
\hline $\begin{array}{l}\text { 5,7-dimethoxy-4- } \\
\text { p- } \\
\text { methoxylphenylc } \\
\text { oumarin \& 5,7- } \\
\text { dimethoxy-4- } \\
\text { phenylcoumarin }\end{array}$ & Coumarins & Antifungal & $\begin{array}{l}\text { Streptomyces } \\
\text { aureofaciens } \\
\text { CMUAc130 }\end{array}$ & $\begin{array}{l}\text { Zingiberoffi } \\
\text { cinale Rosc. }\end{array}$ & $\begin{array}{l}\text { Taechowisan } \\
\text { et al., } 2005\end{array}$ \\
\hline
\end{tabular}

Endophytic actinomycetes isolated from the leaves of Catharanthes roseus (L.) were tested for their antifungal activity against fungi Candida albicans,Botrytis cinerea, Curvularia lunata, Fusarium oxysporum, Fusarium solani, Rhizoctonia solani and for antibacterial activity against Bacillus subtilis, Staphylococcus aureus, Pseudomonas aeruginosa, Proteus vulgaris. In the 38 Endophytic actinomycetes isolate sixty five percent isolates exhibit antimicrobial activity among them isolate Cr-12, Cr-20 having highest activity (Kafur and Khan, 2011). The Endophytic actinomycetes Streptomyces sp. was evaluated in the field condition and it was very effective against the Oidium sp. the causal organism of powdery mildew of sweet pea (Sangmanee et al., 2009). Endophytic actinomycetes Streptomyces caviscabies/setonii EN16, Streptomyces caviscabies/setonii EN27 dan, Streptomyces caviscabies/setonii EN28 was evaluated against the phytopathogenic fungi Gaeumannomyces graminisv ar. Tritici Ggt) and Rhizoctonia solani AG8 in wheat in both condition either in vitro or in planta. The antifunagal compounds were identified with the help of HPLC (Listiana, 2007).

5,7-dimethoxy- 4-p-methoxylphenyl coumarin and 5,7-dimethoxy-4phenylcoumarin extracted from Streptomyces aureofaciens CMUAc130 Endophytic actinomycetes isolated from the root tissue of Zingiber officinale Rosc. 
(Zingiberaceae) were active against Colletotrichum musae and Fusarium oxysporum, the causative agents of anthracnose of banana and wilt of wheat, respectively (Taechowisan et al., 2005). Banana plants endophytic actinomycete Streptomyces griseorubiginosus-like was evaluated against the Fusarium oxysporum f. sp. cubense revealed that the proportion of antagonistic streptomycetes colonization in healthy roots was higher than the diseased roots (Cao et al., 2004).

\section{Acknowledgement}

We are highly grateful to Department of Biotechnology, Government of India for providing research grant under the project "Institutional Biotechnology Hub" at College of Horticulture \& Forestry, Central Agricultural University, Pasighat-791102, Arunachal Pradesh.

\section{References}

Cao, L., Qiu, Z., Dai, X., Tan, H., Lin, Y., and Zhou, S. 2004. Isolation of Endophytic actinomycetes from roots and leaves of banana (Musa acuminata) plants and their activities against Fusariumoxysporum f. sp. Cubense. W. J. Microbiol. Biotech., 20: 501-504.

Castillo, U., Harper, J.K., Strobel, G.A. et al., 2003. Kakadumycins, novel antibiotics from Streptomyces sp. NRRL 30566, an endophyte of Grevilleapteridifolia. FEMS MicrobiolLett, 234: 183-190.

Castillo, U.F., Strobel, G.A., Ford, E.J., et al., 2002. Munumbicins, widespectrum antibiotics produced by Streptomyces NRRL 30562, endophytic on Kennedianigriscans. Microbiol., 148: 2675-2685.
Castillo, U.F., Strobel, G.A., Mullenberg, K., et al., 2006. Munumbicins E-4 and E-5: novel broad-spectrumantibiotics from Streptomyces NRRL3052. FEMS MicrobiolLett, 255: 296-300.

Chankhamhaengdecha, S., Hongvijit, S., Srichaisupakit, A., Charnchai, P., Panbangred, W. 2013. Endophytic actinomycetes: A Novel Source of Potential Acyl Homoserine Lactone Degrading Enzymes. BioMed. Res. Int., 782847: 8.

Compant, S., Duffy, B., Nowak, J., Clément, C., Barka, E.A. 2005. Use of plant growth-promoting bacteria for biocontrol of plant diseases: principles, mechanisms of action, and future prospects. Appl. Environ. Microbiol., 71: 4951-4959.

Conn, V.M., Walker, A.R., Franco, C.M. 2008. Endophyticactinobacteria induce defense pathways in Arabidopsis thaliana. Mol. $\mathrm{Pl}$. Microbe Interact, 21: 208-218.

El-Gendy, M.M.A., EL-Bondkly, A.M.A. 2010. Production and genetic improvement of a novel antimycotic agent, saadamycin, against dermatophytes and other clinical fungi from endophytic Streptomyces sp. Hedaya48. J. Ind. Microbiol. Biotechnol., 37(8): 831-841.

Igarashi, Y. 2004. Screening of novel bioactive compounds from plantassociated actinomycetes. Actinomycetologica, 18: 63-66.

Kafur, A., Khan, A.B. 2011. Isolation of Endophytic actinomycetes from Catharanthesroseus. L. G. Don leaves and their antimicrobial activity. Iranian J. Biotech., 9(4).

Listiana, B.E. 2007. Production of antifungal compound by Endophytic actinomycetes in wheat plants. Agroteksos, 17(1): 8-14. 
Pandey, P.K., Samanta, R., Yadav, R.N.S. 2016. Plant Beneficial Endophytic Bacteria from the Ethnomedicinal Mussaenda roxburghii (Akshap) of Eastern Himalayan Province, India. Advances in Biology, Article ID 580510, 8 pages. doi:10.1155/2015/580510.

Pandey, P.K., Singh, S., Yadav, R.N.S., Singh, A.K., Singh, M.C.K. 2014. Fungal Endophytes: Promising Tools for Pharmaceutical Science. Int. J. Pharm. Sci. Rev. Res., 25(2): 128138.

Pandey, P.K., Yadav, S.K., Singh, A., Sarma, B.K., Mishra, A., Singh, H.B. 2012. Cross species alleviation of biotic and abiotic stressesby an endophyte Pseudomonas aeruginosa PW09. J. Phytopathol., doi: 10.1111/j.1439-0434.2012.01941.

Sangmanee, P., Bhromsiri, A., Akarapisan, A., 2009. The potential of Endophytic actinomycetes, (Streptomyces sp.) for the biocontrol of powdery mildew disease in sweet pea (Pisumsativum). As. J. Food Ag-Ind., S93-S98.

Shimizu, M., Suzuki, T., Mogami, O., Kunoh, H. 2005. Disease resistance of plants induced by Endophytic actinomycetes. In: Tsuyumu S, Leach JE, Shiraishi T, Wolpert T (eds) Genomic and genetic analysis of plant parasitism and defense. APS. St. Paul., 292-293.

Sun, Y., Cheng, Z., Glick, B.R. 2009. The presence of a 1- aminocyclopropane1-carboxylate (ACC) deaminase deletion mutation alters the physiology of the endophytic plant growth promoting bacterium BurkholderiaphytofirmansPsJN. FEMS MicrobiolLett. 296: 131-136. Taechowisan, T., Lu, C., Shen, Y., Lumyong, S. 2005. Secondary metabolites from endophyticStreptomyces aureofaciensCMUAc130 and their antifungal activity. Microbiol., 151: 1691-1695.

Taechowisan, T., Wanbanjob, A., Tuntiwachwuttikul, P., Taylor, W.C. 2006. Identification of Streptomyces sp. Tc022, an endophyte in Alpiniagalanga, and the isolation of actinomycin D. Ann. Microbiol. 56(2): 113-117.

\section{How to cite this article:}

Pramod Kumar Pandey, Mayanglambam Chandrakumar Singh, Amit Kumar Singh, Siddhartha Singh, Ajai Kumar Pandey, Mahesh Pathak, Mukul Kumar, Ramesh Chandra Shakywar, Raghubir Kumar Patidar and Bishwapati Devi, M. 2016. Arsenal of Endophytic Actinobacterial Microbes. Int.J.Curr.Microbiol.App.Sci. 5(3): 62-66. doi: http://dx.doi.org/10.20546/ijcmas.2016.503.009 